\title{
Pengaruh Substitusi Tepung Tempe pada F100 terhadap Saturasi Transferin
}

\section{The Effect Of F100 with Tempe Substitution on Transferin Saturation}

\author{
Anik Puryatni \\ Laboratorium IImu Kesehatan Anak Rumah Sakit Umum Dr. Saiful Anwar Malang
}

\begin{abstract}
ABSTRAK
Permasalahan status gizi di Indonesia masih merupakan permasalahan kesehatan serius dengan $28.47 \%$ anak berada pada kondisi gizi kurang dan gizi buruk. Upaya untuk mengembangkan bahan pangan bergizi dan terjangkau sangat diperlukan. Penelitian ini dilakukan untuk membuktikan dampak pemberian susu skim dengan substitusi tepung tempe dalam memperbaiki status gizi pada anak dengan malnutrisi. Penelitian dilakukan dengan desain uji klinis pada dua kelompok yang dipilih secara acak, yaitu kelompok dengan suplemen standar WHO dan kelompok dengan substitusi tepung tempe. Data menunjukkan peningkatan signifikan berat badan pada kedua kelompok. Saturasi tranferin meningkat sebesar $13.02+7.87$ pada kelompok dengan pemberian suplemen standar WHO F100, sedangkan kelompok dengan substitusi tepung tempe meningkat sebesar $12.47+5.317$. Tidak ada perbedaan signifikan peningkatan berat badan antar dua kelompok. Hal ini menunjukkan bahwa pemberian substitusi dengan tempe kedele dapat memberikan efek yang sama dengan suplemen standar WHO F100 pada anak dengan dengan malnutrisi.
\end{abstract}

Kata Kunci: Anak, berat badan, F100, malnutrisi, saturasi transferin, tepung tempe

\section{ABSTRACT}

Nutritional problem in Indonesia remain a serious health problem, with $28.47 \%$ children in under nutrition and severe malnutrition. Efforts to develop affordable food is needed. This research is aimed to measure the impact of skim milk with tempe flour substitution in improving nutrition status for malnourished children. A randomized clinical trial was performed in control group with WHO standard diet and treatment group with tempe flour substitution diet. The results showed a significant increase of body weight in both groups $(p<0.05)$. Transferin saturation increased $13.02+7.87$ in the standard F100 group, while the substitution group increased $12.47+5.317$, but the change is not significant differences in both groups. This result shows that the substitution of soybean tempe can be used as the alternative for F100 standard diet.

Keywords: Body weight, children, F100, malnutrition, tempe flour, transferin saturation

Jurnal Kedokteran Brawijaya, Vol. 26, No. 2, Agustus 2010; Korespondensi: Anik Puryatni. Laboratorium Ilmu Kesehatan Anak. Rumah Sakit Umum Dr. Saiful Anwar Malang, Jl. Jaksa Agung Suprapto No. 2 Malang Tel. (0341)343343 Email: Puryatni@yahoo.co.id 


\section{PENDAHULUAN}

Indonesia masih menghadapi permasalahan gizi yang cukup serius. Menurut Susenas tahun 2005 angka prevalensi gizi kurang anak balita $28 \%$, dan di antara angka tersebut 8,8\% menderita gizi buruk (1,2). Pada tahun 2008 dari hasil Riskesdas angka gizi kurang menurun menjadi $13,0 \%$. Walau prevalensi gizi kurang menurun namun anak yang stunting (pendek) masih cukup tinggi $(36,8 \%)$ yang menunjukkan pernah menderita kekurangan gizi. Masalah gizi di Indonesia masih terjadi di 77,3\% kabupaten dan $56 \%$ kota. Sebanyak lima juta anak balita $(27,5 \%)$ kurang gizi dengan 3,5 juta (19,2\%) diantaranya berada pada tingkat gizi kurang dan 1,5 juta ( $8,3 \%$ ) sisanya mengalami gizi buruk (3). Rendahnya status gizi berdampak pada kualitas sumber daya manusia. Status gizi mempengaruhi kecerdasan, daya tahan tubuh terhadap penyakit, kematian bayi, kematian ibu, dan produktivitas kerja. Hal ini mendorong perlunya program perbaikan status gizi bagi semua anak.

WHO merekomendasikan formula makanan standar untuk penanganan gizi buruk, yaitu formula WHO dalam bentuk F75, F100, dan F135. Formula WHO F100 dikenal sebagai formula catch up, dengan kandungan $100 \mathrm{kcal}$ per $100 \mathrm{ml}$. Formula ini mengandung energi, lemak dan protein yang tinggi. Komponen utama sumber protein yang digunakan pada F100 adalah protein susu $(4,5)$.

Malnutrisi disebabkan oleh masalah krisis ekonomi, politik dan juga sosial (6). Penggunaan bahan dasar susu skim dalam F100 perlu dipertimbangkan dalam penerapannya di masyarakat, mengingat kendala harga yang mahal dan sulit tersedia di beberapa daerah. Selain itu susu juga tidak dapat digunakan pada beberapa kasus, salah satunya pada penderita yang alergi dengan susu sapi.

Adanya beberapa keterbatasan penggunaan susu sebagai bahan dasar formula untuk anak dengan gizi kurang atau gizi buruk, mendorong pengembangan alternatif formula untuk anak dengan gizi kurang atau gizi buruk. Alternatif tersebut misalnya dengan mengganti susu dengan bahan dasar lain yang merupakan bahan pangan lokal yang mudah didapat dan harganya murah tetapi tetap memperhatikan nilai gizinya, misalnya formula tempe.

Penelitian mengenai manfaat pemberian tempe di masyarakat maupun dalam terapi klinis yang sudah dilakukan menunjukkan hasil yang positif. Pemberian suplementasi formula tempe terhadap anak gizi kurang di Sulawesi Utara menunjukan peningkatan status gizi secara signifikan (7). Pemberian tempe pada anak diare menunjukan penurunan lama diare dan kenaikan berat badan lebih tinggi $(8,9)$. Penelitian tentang pengaruh pemberian tempe sudah dikembangkan dalam bentuk formula tepung tempe, maupun susu tempe (10). Tepung tempe juga telah dicoba penggunaannya untuk berbagai keperluan penyediaan pangan bagi orang-orang yang dalam keadaan rawan gizi maupun sebagai bahan campuran untuk membuat jenis makanan dalam rangka meningkatkan nilai gizi protein pada makanan olahan (11) Penelitian yang dilakukan pada pasien sirosis hepatis dengan pemberian diet tempe dan tepung tempe menunjukan peningkatan kadar albumin dan kadar hemoglobin secara bermakna. Hanya saja pemeriksaan status zat besi dalam tubuh seperti pemeriksaan transferin dan ferritin belum dilakukan (12).

Transferin adalah glikoprotein yang termasuk golongan serum globulin-ß1 yang berfungsi sebagai pengusung ion zat besi di dalam sirkulasi tubuh menuju hati, limpa dan sumsum tulang. Kadar transferin yang secara tidak langsung digambarkan sebagai saturasi transferin merupakan salah satu parameter yang sensitif untuk mengevaluasi status nutrisi (13-15).

Penelitian ini dilakukan untuk mengkaji efektifitas substitusi bahan dasar F100 dengan tepung tempe dalam terapi diet pada anak gizi kurang yang dirawat di rumah sakit dengan melihat pengaruhnya terhadap saturasi transferin.

\section{METODE}

Penelitian dilakukan dengan desain randomized clinical trial dengan kontrol pada balita gizi kurang. Subjek dibagi dalam 2 kelompok yaitu kelompok perlakuan yang diberikan F100 dengan bahan dasar yang di substitusi dengan tepung tempe dan kelompok kontrol yang di beri F100 standar rumah sakit (WHO). Penelitian dilakukan pada bulan Februari sampai dengan April 2010 di Laboratorium/SMF IKA RSU Dr. Saiful Anwar Malang untuk pemberian perlakuan dan Laboratorium Patologi Klinik untuk pemeriksaan laboratorium Total Iron Binding Capacity (TIBC) dan saturasi transferin.

Populasi penelitian adalah balita gizi kurang berdasarkan pengukuran antropometri yang dirawat inap pada bulan Februari sampai dengan April 2010. Kriteria inklusi yang digunakan adalah pasien berusia 1-10 tahun, suka atau mau minum susu, mendapatkan diet oral, rasio BB/TB dengan nilai $z$ score $<-2$, bersedia dijadikan subjek penelitian yang ditunjukkan dengan kesediaan orang tua menandatangani proxy consent. Kriteria eksklusi yang digunakan adalah penderita yang diberikan terapi suplemen Fe, mempunyai alergi susu sapi, menderita intoleransi lakstosa dan gangguan fungsi ginjal dan hati. Subjek penelitian dikelompokkan menjadi dua secara random dengan menggunakan randomized block design. Kelompok perlakuan mendapatkan diet oral standar rumah sakit dan diberikan F100 dengan substitusi tepung tempe sedangkan kelompok kontrol mendapatkan diet oral standar rumah sakit dan F100 standar sebanyak 3 kali $200 \mathrm{ml} /$ hari, selama 7 hari pengamatan.

Tepung tempe diperoleh dari tempe segar melalui proses pengirisan, pengukusan/blanching, pengeringan, penggilingan dan penyaringan dengan ukuran 80 mesh (16).

Diet F100 dengan substitusi tepung tempe adalah formula cair yang mengandung energi $101 \mathrm{kcal}$, protein 3,07 g dengan komposisi 6,8 $\mathrm{g}$ tepung tempe, $3 \mathrm{~g}$ gula pasir, $5 \mathrm{~g}$ minyak kelapa dan $2 \mathrm{ml}$ larutan elektrolit dan $100 \mathrm{ml}$ air. Diet F100 standar rumah sakit adalah makanan formula cair standar WHO yang mengandung energi $101 \mathrm{kcal}$, protein 3,09 g dengan komposisi 8,5 g susu skim, 5 g gula pasir, $6 \mathrm{~g}$ minyak kelapa dan $2 \mathrm{ml}$ larutan elektrolit dan 100 
Tabel 1. Komposisi zat gizi formula

\begin{tabular}{|c|c|c|c|c|c|c|}
\hline \multirow[t]{2}{*}{ Komposisi Penyusun } & \multirow[t]{2}{*}{ Berat } & \multicolumn{5}{|c|}{ Nilai Gizi } \\
\hline & & $\begin{array}{r}\text { Energi } \\
(\mathrm{kcal})\end{array}$ & $\begin{array}{r}\text { Protein } \\
\text { (g) }\end{array}$ & Lemak (g) & $\mathrm{KH}(\mathrm{g})$ & $\begin{array}{c}\mathrm{Fe} \\
\text { (mg) }\end{array}$ \\
\hline Formula F100 standar & & 101.17 & 3.09 & 5.97 & 9.12 & 0,085 \\
\hline Susu skim (g) & 8.5 & 30.77 & 3.03 & 0.09 & 4.42 & 0,085 \\
\hline Gula pasir (g) & 5 & 18.20 & 0.00 & 0.00 & 4.70 & 0,00 \\
\hline Minyak kelapa (g) & 6 & 52.20 & 0.06 & 5.88 & 0.00 & 0,00 \\
\hline Elektrolit (ml) & 2 & & & & & \\
\hline Air (ml) & 100 & & & & & \\
\hline Formula Substitusi F100 & & 101,52 & 3.07 & 6,94 & 7,00 & 0,612 \\
\hline Tepung Tempe (g) & 6.8 & 47,10 & 3.02 & 2.04 & 4.18 & 0,612 \\
\hline Gula pasir (g) & 3 & 10,92 & 0,00 & 0,00 & 2,82 & 0,00 \\
\hline Minyak kelapa (g) & 5 & 43,5 & 0.05 & 4,90 & 0,00 & 0,00 \\
\hline Elektrolit (ml) & 2 & & & & & \\
\hline Air (ml) & 100 & & & & & \\
\hline
\end{tabular}

\section{ml air (Tabel 1).}

Data berat dan tinggi badan diukur sebelum dan sesudah penelitian. Berat badan pasien diukur menggunakan timbangan berat badan dengan skala ketelitian 0,5 kg sedangkan tinggi badan diukur dengan menggunakan microtoise dengan ketelitian 0,1 cm. Pengambilan sampel darah untuk pemeriksaan TIBC dan saturasi transferin sebelum dan sesudah perlakuan dikerjakan oleh perawat terlatih kemudian dikirim ke Laboratorium Patologi Klinik.

Seluruh data yang terkumpul kemudian diklasifikasikan menurut jenisnya, dianalisis dengan menggunakan perangkat lunak SPSS Version 12. Analisis data diawali secara deskriptif, uji homogenitas dan uji normalitas untuk melihat karakteristik data dengan metode onesample Kolmogorov-Smirnov test. Data dianalisis dengan uji paired sample t-test.

\section{HASIL}

Pengumpulan sampel dilakukan selama periode April sampai dengan Agustus 2010. Didapatkan 42 sampel kemudian menjadi 40 sampel karena 2 sampel orang tuanya menolak menandatangani proxy consent. Subjek penelitian yang memenuhi. Kriteria inklusi dan orang tua bersedia menandatangani informed consent berjumlah 36 orang. Pengambilan data dilakukan secara langsung (wawancara dan recall pada makan pasien), maupun secara tidak langsung (pengambilan data dari rekam medis) dan pengambilan sampel darah untuk pre test data laboratorium.

Selama penelitian berlangsung drop out subjek penelitian terjadi sebanyak 7 orang dengan rincian, 2 orang karena tidak bersedia diambil sampel darah pada saat post test, 1 karena tidak bisa dilakukan pengambilan darah oleh karena penyakitnya, 2 orang menolak dilakukan home visite, 2 orang menolak mengkonsumsi formula sisa dan 1 orang sampel dijadikan cadangan. Pasien yang pulang sebelum selesai hari pengamatan diberikan formula untuk dikonsumsi selama di rumah dan dilakukan home visite 3 hari sekali.

Karakteristik subjek penelitian dalam penelitian ini digambarkan menurut umur, jenis kelamin dan diagnosa medis. Selanjutnya dilakukan uji chi square terhadap karakteristik kedua kelompok (Tabel 2). Hasil menunjukkan bahwa tidak ada perbedaan yang bermakna antara kedua kelompok dalam aspek umur, jenis kelamin dan diagnosa medis. Diharapkan faktor tersebut tidak mempengaruhi efek pemberian formula pada pasien.

Tabel 2. Karakteristik subjek penelitian

\begin{tabular}{|c|c|c|c|c|}
\hline \multirow{2}{*}{ Variable } & \multicolumn{2}{|c|}{ Kelompok Perlakuan } & \multirow{2}{*}{$\chi^{2}$} & \multirow{2}{*}{$p$-value } \\
\hline & FS100 (\%) & F100 (\%) & & \\
\hline \multicolumn{5}{|l|}{ Umur } \\
\hline $1-3$ th & 21,88 & 12,5 & 2,872 & 0,412 \\
\hline $4-6$ th & 9,38 & 12,5 & & \\
\hline $7-9$ th & 15,62 & 12,5 & & \\
\hline 10 th & 3,125 & 12,5 & & \\
\hline \multicolumn{5}{|l|}{ Jenis kelamin } \\
\hline Laki -laki & 12,5 & 28,13 & & \\
\hline Perempuan & 37,5 & 21,88 & 3,239 & 0,072 \\
\hline \multicolumn{5}{|c|}{ Diagnosa medis } \\
\hline Infeksi & 31,25 & 34,38 & & \\
\hline Non infeksi & 18,75 & 15,63 & 0,139 & 0,710 \\
\hline
\end{tabular}

\section{Pengaruh Substitusi Tempe pada Perubahan Berat Badan}

Berat badan sampel diukur pada saat awal penelitian dan pada saat akhir penelitian atau sesudah intervensi. Perubahan berat badan diketahui dengan menghitung selisih berat badan akhir dan awal penelitian, yang 
diketahui sebagai delta berat badan sampel. Berdasarkan uji analitis kenormalan diketahui bahwa data berat badan terdistribusi secara normal, sehingga data berat badan dengan skala rasio dapat dianalisis secara parametrik.

Selisih rerata berat badan sebelum dan sesudah intervensi menunjukkan peningkatan berat badan setelah dilakukan intervensi baik pada kelompok F100 maupun FS100. Analisis dengan menggunakan uji paired t test dilakukan untuk melihat perbedaan berat badan sebelum dan sesudah intervensi pada masing-masing perlakuan.

Hasil penelitian (Tabel 3) menjelaskan bahwa terdapat perbedaan yang bermakna dari berat badan sebelum dan sesudah intervensi pada masing-masing kelompok perlakuan $(p<0,05)$. Artinya rata-rata berat badan sebelum dan sesudah intervensi pemberian formula baik FS100 maupun F100 mengalami perubahan yang signifikan.

Tabel 3. Analisis paired t test berat badan sebelum dan sesudah intervensi

\begin{tabular}{lcccc}
\hline Perlakuan & \multicolumn{2}{c}{ Berat Badan } & t & $p$-value \\
& Sebelum & Sesudah & & \\
\hline F100 & $14,21 \pm 5,78$ & $14,87 \pm 6,78$ & $-3,671$ & $0,002^{*}$ \\
FS100 & $14,05 \pm 5,82$ & $14,87 \pm 6,82$ & 5,213 & $0,000^{*}$ \\
\hline
\end{tabular}

\section{Perubahan Kadar Saturasi Transferin}

Kadar saturasi transferin diketahui dari sampel darah yang diambil dari subjek dalam penelitian ini. Kemudian dianalisis menggunakan metode di laboratorium sentral rumah sakit dr. Saiful Anwar Malang. Data kadar saturasi transferin merupakan data numerik dengan skala rasio sehingga dilakukan uji kenormalan lebih dahulu untuk melihat sebaran datanya. Berdasarkan uji kenormalan dengan metode one-sample Kolmogorov-Smirnov test. Hasil pengujian tersebut menunjukkan bahwa semua data terdistribusi normal ( $p>0.05$ ). Data kemudian diuji dengan metode paired sample t-test untuk mengetahui perbedaan rata-rata kadar saturasi transferin sebelum dan sesudah diberi perlakuan.

Perubahan saturasi transferin dari penelitian didapatkan nilai $p<0.05$ yang artinya bahwa ada perbedaan yang bermakna pada kadar saturasi transferin anak yang diberi perlakuan tepung tempe dan F100. Hal ini juga tampak pada hasil rata-rata kedua kelompok yang tampak adanya peningkatan kadar saturasi transferin antara sebelum dan sesudah perlakuan (Tabel 4).

\section{Tabel 4. Analisis paired t-test saturasi transferin}

\begin{tabular}{lllll}
\hline \multirow{2}{*}{ Perlakuan } & \multicolumn{2}{c}{ Rerata Kadar Saturasi Transferrin } & \multirow{2}{*}{ T } & $p$ value \\
\cline { 2 - 3 } & \multicolumn{1}{c}{ Sebelum } & Sesudah & & \\
\hline F100 & $25.13 \pm 15.464$ & $37.87 \pm 23.366$ & -4.077 & $0.001^{*}$ \\
FS100 & $19.47 \pm 9.665$ & $27.07 \pm 12.618$ & -4.219 & $0.001^{*}$ \\
\hline
\end{tabular}

Perubahan saturasi transferin yang terjadi pada kedua kelompok didapatkan nilai $p=0.221$. Hal ini dapat menunjukkan bahwa tidak terdapat perbedaan yang signifikan terhadap peningkatan kadar saturasi transferin baik pada kelompok yang diberi formula substitusi tepung tempe maupun F100 standar ( $p>0.05$ ) (Tabel 5).

Tabel 5. Delta saturasi transferin

\begin{tabular}{lll}
\hline Perlakuan & $\begin{array}{l}\text { Rata - Rata delta Saturasi } \\
\text { Transferrin }\end{array}$ & $p$ value \\
\hline F100 & $13.02 \pm 7.870$ & 0.221 \\
FS100 & $12.47 \pm 5.317$ & \\
\hline
\end{tabular}

\section{DISKUSI}

Tempe tidak hanya dibuat dari bahan kedelai, tempe dapat dibuat dari berbagai bahan baik dengan bahan dasar legume yaitu tanaman kacang-kacangan berkeping dua maupun dengan bahan dasar bukan legume yaitu tempe yang dibuat dari produk samping, misalnya ampas kelapa atau biji-bijian berkeping tunggal (11). Dalam penelitian ini, tempe yang digunakan adalah tempe dengan bahan dasar kacang kedelai.

Tempe kedelai merupakan bahan pangan hasil fermentasi kedelai dengan menggunakan jamur Rhizopus sp. Kapang Rhizopus sp dalam proses pertumbuhannya menghasilkan beberapa enzim yang mampu menghidrolisis senyawa kompleks menjadi senyawa yang lebih sederhana sehingga tempe menjadi bahan pangan yang lebih mudah dicerna dan mempunyai nilai gizi lebih dibandingkan kedelai (17).

Tempe merupakan sumber protein yang murah harganya dan mudah didapat. Nilai gizi protein tempe tidak berbeda jauh dengan bahan makanan sumber protein lain seperti daging, ikan dan telur. Tabel 6 menunjukkan perbandingan nilai gizi antara tempe dengan bahan makanan sumber protein lainnya (18).

Tempe mempunyai masa simpan yang rendah yaitu 2-3 hari pada suhu ruang, setelah melewati masa itu jamur tempe akan mati dan selanjutnya enzim proteolitik akan merombak protein tempe sehingga tempe menjadi busuk (10). Tempe dapat diawetkan dalam bentuk tepung tempe sehingga tempe menjadi lebih fleksibel dalam penggunaannya dan lebih lama masa simpannya. Tepung tempe diperoleh dari tempe segar melalui proses pengirisan, pengukusan/blanching, pengeringan, penggilingan dan penyaringan ukuran 80 mesh. Tempe segar yang telah ditepungkan, ternyata masih mengandung nilai gizi yang cukup (11). Formula yang dipergunakandalam penelitian adalah F100 substitusi dengan tepung tempe serta F100 standar, dengan mempunyai kandungan nutisi yang hampir sama.

Hasil menunjukkan substitusi tempe memberikan perbaikan berat badan dan saturasi transferin setara dengan formula standar. Saturasi transferin menunjukkan jumlah iron binding sites dan besi transport pada cadangan besi dengan menghitung perbandingan antara konsentrasi 
Tabel 6. Komposisi gizi bahan makanan sumber protein nabati dan protein hewani per $100 \mathrm{~g}$ bahan

\begin{tabular}{|c|c|c|c|c|c|c|}
\hline Komponen & Tempe & Kedelai & $\begin{array}{l}\text { Daging } \\
\text { sapi }\end{array}$ & $\begin{array}{l}\text { Daging } \\
\text { ayam }\end{array}$ & $\begin{array}{l}\text { Telur } \\
\text { ayam }\end{array}$ & Ikan mas \\
\hline Kalori (kal) & 149 & 286 & 207 & 302 & 154 & 86 \\
\hline Protein (g) & 18,3 & 30,2 & 18,8 & 18,2 & 12,4 & 16 \\
\hline Lemak (g) & 4 & 15,6 & 14 & 25 & 10,8 & 2 \\
\hline Karbohidrat (g) & 12,7 & 30,1 & 0 & 0 & 0,7 & 0 \\
\hline Kalsium (mg) & 129 & 196 & 11 & 14 & 86 & 20 \\
\hline Fosfor (mg) & 154 & 506 & 170 & 200 & 258 & 150 \\
\hline Besi (mg) & 10 & 6,9 & 2,8 & 1,5 & 3 & 0,05 \\
\hline Vit. A. (SI) & 50 & 95 & 30 & 180 & 900 & 150 \\
\hline Vit B1 (mg) & 0,17 & 0,96 & 0,08 & 0,008 & 0,10 & 0,05 \\
\hline Air (g) & 64 & 20 & 66 & 55,9 & 74,3 & 80 \\
\hline
\end{tabular}

serum besi dengan TIBC yang dinyatakan dalam persen, keadaan normal saturasi transferin sekitar 33\% (20-50\%) $(13,14)$. Saturasi transferin yang rendah menunjukkan rendahnya kadar serum iron relatif terhadap jumlah ironbinding sites yang menandakan rendahnya cadangan besi. Saturasi transferin turun sebelum timbulnya anemia sehingga lebih sensitif terhadap perubahan status besi dalam tubuh bila dibandingkan dengan indeks eritrosit maupun Hemoglobin $(14,19)$. Kadar transferin yang

\section{DAFTAR PUSTAKA}

1. Badan Pusat Statistik Republik Indonesia. Balita (059 bulan) Menurut Status Gizi Tahun 1998-2005 (\%). (Online). http://www.bps.go.id/tab sub /view.php?tabel=1\&daftar=1\&id_subyek=30\&nota $b=40$

2. Departemen Kesehatan RI. Profil Kesehatan Indonesia 2005. Jakarta; 2007.

3. Andewi-Setditjen. Penatalaksanaan Gizi Buruk di Masyarakat. (Online)2005. http//www.gizikia. depkes/archives/816 [diakses tanggal 14 Februari 2011]

4. WHO. Management of Severe Malnutrition: a Manual for Physicians and Other Senior Health Workers. Geneva: World Health Organization; 1999.

5. Diop EHI, Dossou NI, Ndour MM, Briend A, and Wade S. Comparison of the Efficacy of a Solid Readyto-use Food and a Liquid, Milk-Based Diet for the Rehabilitation of Severely Malnourished Children: a Randomized Trial. The American Journal of Clinical Nutrition. 2003; 78(2): 302-307.

6. Soekirman. Ilmu Gizi dan Aplikasinya untuk Keluarga dan Masyarakat. Malang: Ditjen Dikti Departemen Pendidikan Nasional; 2000.

7. Hadju V, Taslim NA, Tawali A, and Thaha R. Effect of Tempe Formula Supplementation Through Posyandu on Nutritional Status of Children in South Sulawesi. Jurnal Kedokteran YARSI. 2004; 12(2): 1322. secara tidak langsung digambarkan sebagai saturasi transferin merupakan salah satu parameter yang sensitif untuk mengevaluasi status nutrisi $(14,15)$.

Pemberian substitusi tepung tempe sebagai bahan dasar Formula 100 dapat meningkatkan status nutrisi yang sama baiknya dengan Formula 100 standar yang dibuktikan dengan peningkatan berat badan serta saturasi transferin.

8. Partawihardja SI. Pengaruh Suplementasi Tempe terhadap Kecepatan Tumbuh pada Penderita Diare Anak Umur 6-24 Bulan. [Disertasi]. Universitas Diponegoro, Semarang. 1990

9. Soenarto Y, Sudigbia I, dan Hermana. Antidiarrheal Characteristics of Tempe Produced Traditionally and Industrially in Children Aged 624 Months with Acute Diarrhea. Prosiding Lokakarya Pemanfaatan Tempe untuk Peningkatan Status Gizi dan Kesehatan. Jakarta, 13 Oktober 1997.

10. Kasmidjo RB. Tempe Mikrobiologi dan Biokimia Pengolahan Serta Pemanfaatannya. Yogyakarta: Pusat Antar Universitas Pangan dan Gizi UGM; 1990.

11. Hermana, Karmini, dan Karyadi . Komposisi dan Nilai Gizi Tempe serta Manfaatnya dalam Peningkatan Mutu Gizi Makanan. Di dalam: Sapuan dan Sutrisno N (Ed). Bunga Rampai Tempe Indonesia. Jakarta: Yayasan Tempe Indonesia; 1996; hal. 61-66.

12. Ratnasari N. Manfaat Diet Tempe Kedelai pada Penderita Sirosis Hati. [Tesis]. Universitas Gadjah Mada, Yogyakarta. 2000.

13. Glader B. Iron-Deficiency Anemia. In: Behrman RE, Kliegman RM, Jenson HB (Eds). Nelson Textbook of Pediatrics 18th edition. New York: Mc Graw-Hill; 2004; hal. 1614-1616.

14. Hilman RS and Ault KA. Hematology in Clinical Practice a Guide to Diagnosis and Management. New York: Mc Graw-Hill; 2002; p. 51-61. 
15. Cook JD, Flowers $\mathrm{CH}$, and Skikne BS. The Quantitative Assessment of Body Iron. Blood. 2003; 101(9): 3359-3364.

16. Rachmawati, Minta, dan Fransisca S. Kegunaan Tepung Tempe. Jakarta: PDII - LIPI; 2000.

17. Astawan. Sehat dengan Tempe. Jakarta: PT. Dian Rakyat; 2008.
18. Mahmud dan Mien K. Daftar Komposisi Bahan Makanan. Jakarta: PERSAGI; 2005.

19. Mulyati. Prediksi Peningkatan Kadar Hb pada Anak Bawah Tiga tahun Anemia Setelah Mendapat Intervensi Zat Besi di Desa Pagelaran, Ciomas Bogor. [Tesis]. Universitas Gajah Mada, Yogyakarta. 2000. 